\title{
Protein, Calcium, Zinc, and Iron Contents of Finger Millet Grain Response to Varietal Differences and Phosphorus Application in Kenya
}

\author{
Wekha N. Wafula ${ }^{1,2, *}$, Nicholas K. Korir ${ }^{1}$, Henry F. Ojulong ${ }^{2}$, Moses Siambi ${ }^{2}$ and \\ Joseph P. Gweyi-Onyango ${ }^{1}$ \\ 1 Department of Agricultural Science and Technology, Kenyatta University, P.O. Box 43844-00100 Nairobi, \\ Kenya; korir.nicholas@ku.ac.ke (N.K.K.); josephonyango2002@yahoo.co.uk (J.P.G.-O.) \\ 2 International Crops Research Institute for the Semi-Arid Tropics, ICRAF House, UN Avenue, Gigiri, \\ P.O. BOX 39063-00623 Nairobi, Kenya; h.ojulong@cgiar.org (H.F.O.); m.siambi@cgiar.org (M.S.) \\ * Correspondence: nelwaf@gmail.com
}

Received: 24 July 2017; Accepted: 22 November 2017; Published: 24 February 2018

\begin{abstract}
This study was carried out to investigate the influence of phosphorus fertilizers on the concentrations of nutrients, particularly calcium, protein, zinc, and iron in finger millet grains grown in different agro-ecologies in Kenya. The on-station experiments were carried out at Kiboko (Eastern Kenya), Kakamega, and Alupe (Western Kenya) in 2015 during the short and long rainy seasons. The trials were laid out in a randomized complete block design (RCBD) in a $4 \times 3$ factorial arrangement with three replicates. The treatments comprised of four levels of phosphorus $(0,12.5,25.0$ and $37.5 \mathrm{~kg} \mathrm{ha}^{-1} \mathrm{P}_{2} \mathrm{O}_{5}$ ) and three finger millet varieties (U-15, P-224 and a local variety). Application of phosphorus significantly $(p \leq 0.05)$ increased the protein content of finger millet grain in varieties in all the three sites. Variety U-15 had the highest protein content $(11.0 \%)$ at $25 \mathrm{~kg} \mathrm{ha}^{-1} \mathrm{P}_{2} \mathrm{O}_{5}$ with the control (zero P) on variety P-224 eliciting the lowest (4.4\%) at Kiboko. At Kakamega, the $25 \mathrm{~kg} \mathrm{ha}^{-1}$ $\mathrm{P}_{2} \mathrm{O}_{5}$ treatment with $\mathrm{U}-15$ variety had the highest protein content $(15.3 \%)$ while the same variety at $12.5 \mathrm{~kg} \mathrm{ha}^{-1} \mathrm{P}_{2} \mathrm{O}_{5}$ rate elicited the highest protein content (15.0\%) at Alupe. Phosphorus application significantly enhanced the nutritional quality of finger millet grains specifically protein, calcium, iron, and zinc. Variety P-224 had the highest calcium content in all sites and highest iron content at Kakamega while the local varieties had the highest zinc content in all sites. The varieties responded differently to each quality component but generally, based on the protein content, the $25 \mathrm{~kg} \mathrm{ha}^{-1}$ $\mathrm{P}_{2} \mathrm{O}_{5}$ is recommended.
\end{abstract}

Keywords: finger millet; phosphorus; nutrients; protein; polynomial; nutritional quality

\section{Introduction}

Finger millet (Eleusine coracana (L.) Gaertn) is a cereal grass mostly grown for its grain. It is a robust and tillering annual grass of up to $170 \mathrm{~cm}$ high [1-3]. The inflorescence is a panicle with 4-19 finger-like spikes that resemble a fist when mature, hence the name finger millet [1]. The spikes bear up to 70 alternate spikelets, carrying four to seven small seeds [4]. The seed pericarp is independent from the kernel and can be separated easily from the seed coat. Finger millet is a staple food in many of the Southern Asia and African countries where it is one of the major cultivated crops compared to the other regions of the world. It is easily stored for a longer period than most cereals and therefore it is considered as a useful famine crop [3]. The grain is highly nutritious, digestible and multipurpose whereby it can be cooked or ground to make flour for porridge or used to make cakes [2]. Sprouted grains are recommended for infants and elderly people. Finger millet is also used to make liquor and beer, which yields byproducts used for livestock feeding. 
In Kenya, most people depend on rice, wheat, and maize for the energy requirements. This monotony has been identified as a possible contributor to the prevalence of many non-communicable diseases [5]. The richness in dietary fiber, calcium, polyphenol, and protein content in millets make them unique among the cereals [6,7]. Finger millet contains $44.7 \%$ compared to $33.9 \%$ of essential amino acids that is found in the Food and Agricultural Organization's reference protein as a proportion of the total amino acids content [8,9]. Generally, millets have higher fat content than maize, rice, and sorghum and contain significant amounts of methionine and cysteine as well as threonine, tryptophan, isoleucine, and valine [10]. Millets are not only comparable to major cereals with respect to their nutritional features but are very good sources of carbohydrates, micronutrients, and phytochemicals with nutraceutical properties. Finger millet contains the highest calcium content (300-350 mg/100 g) among the small millets [11].

Decline in crop yields and to an extent nutritional status is mainly caused by loss of soil fertility where factors such as erosion, nutrient imbalance, and inherently low soil fertility plays an important role. In humid and sub-humid acid soils, phosphorus $(\mathrm{P})$ is one of the critical elements that limit crop production [12]. The situation is aggravated in smallholder finger millet farms where use of mineral fertilizers is limited or non-existent [13]. The grains of finger millet, being nutritionally superior to rice and wheat, provide alternative source of low cost proteins, especially for poor households. However, low yields of finger millet are attained because most Kenyans live on land with low potential for agriculture and so-called marginal lands with poor soil fertility. Such land accounts for above 80 percent of Kenya's total area. The current study was carried out to evaluate the influence of phosphorus fertilizer on the grain nutritional quality of three finger millet varieties, particularly with respect to protein, calcium, iron, and zinc.

\section{Materials and Methods}

\subsection{Description of the Experimental Sites}

Field experiments were conducted at three on-station sites at Kiboko, Kakamega, and Alupe. Kiboko crops research station lies at $975 \mathrm{~m}$ above sea level in Makueni County of Eastern Kenya at latitude $37^{\circ} 38^{\prime} 60^{\prime \prime} \mathrm{E}$ and longitude $2^{\circ} 16^{\prime} 0^{\prime \prime} \mathrm{S}$. The area experiences semi-arid tropical climate with mean annual maximum temperature of $28.6^{\circ} \mathrm{C}$. Kakamega field crop station is situated in Kakamega County of Western Kenya at $1523 \mathrm{~m}$ above sea level within latitude $0^{\circ} 16^{\prime} 60^{\prime \prime} \mathrm{N}$ and longitude $34^{\circ} 45^{\prime} 0^{\prime \prime} \mathrm{E}$. Alupe crops research station is located in Busia County of western Kenya at $1157 \mathrm{~m}$ above sea level within latitude $0^{\circ} 30^{\prime} 15^{\prime \prime} \mathrm{N}$ and longitude $34^{\circ} 07^{\prime} 50^{\prime \prime} \mathrm{E}$.

Collection of soil samples before planting was done on the plough layer $(0-30 \mathrm{~cm})$ from all the experimental fields in the study sites. The soil $\mathrm{pH}$ (water) was determined electrometrically, nitrogen was determined by the Macro Kjedahl method, phosphorus was determined by the Olsen method, and the soil organic carbon was determined using the Walkley-Black wet oxidation method. Analytical results indicated low $\mathrm{P}$ and moderately acidic soils in Busia and Kakamega while soil P in Makueni was mode and alkaline (Table 1).

Table 1. Initial soil properties of the study sites in 2015.

\begin{tabular}{cccc}
\hline & Busia & Kakamega & Kiboko \\
\hline pH & 5.2 & 5.6 & 9.3 \\
Phosphorus (ppm) & 5.0 & 6.0 & 13.0 \\
Nitrogen (\%) & 0.03 & 0.1 & 0.08 \\
Organic Carbon (\%) & 3.4 & 2.3 & 0.24 \\
Zinc (ppm) & 1.5 & 9.9 & 5.0 \\
Iron (ppm) & 28.5 & 59.3 & 41.5 \\
Calcium (\%) & 10.7 & 2.8 & 2.9 \\
\hline
\end{tabular}




\subsection{Experimental Design and Treatments}

Treatments in the study comprised of three varieties (U-15, P-224, and a Local variety) and four phosphorus rates $\left(0,12.5,25.0\right.$, and $\left.37.5 \mathrm{~kg} \mathrm{ha}^{-1} \mathrm{P}_{2} \mathrm{O}_{5}\right)$. The $0 \mathrm{~kg} \mathrm{ha}^{-1} \mathrm{P}_{2} \mathrm{O}_{5}$ rate was the absolute control whereas Ikhulule was the local variety at Kakamega and Alupe while in Kiboko Ekalakala was the local variety check. The experiment was laid out in a randomized complete block design with three replications in a factorial arrangement. The crop was planted by hand drilling and phosphorus supplied as triple superphosphate applied at planting. Standard cultural practices were followed during the growing period as recommended for finger millet. The experiments were carried out for two growing seasons in 2015, the long rains (March to August) and the short rains (September to December).

\subsection{Laboratory Analyses}

Half a kilogram of dried grain samples from each experimental unit were collected and taken for analyses. The samples were ground and passed through a 2-mm screen and analyzed for nitrogen $(\mathrm{N})$, calcium $(\mathrm{Ca})$, iron $(\mathrm{Fe})$, and zinc $(\mathrm{Zn})$. The concentration of total $\mathrm{N}$ was determined using a Macro-N-Analyzer (Elementar Hanau Systems, VAP-30 Model, Hanau, Germany) following the Micro-Kjeldhal method as described by Association of Official Analytical Chemists (AOAC) [14]. Nitrogen was converted into protein by multiplying it by the protein factor of $6.25(\mathrm{~N} \times 6.25)$. Calcium, zinc, and iron were determined by the atomic absorption spectrophotometer method following the procedures described by the AOAC [14].

\subsection{Statistical Analysis}

Analysis of variance (ANOVA) was conducted on the collected data using GenStat statistical software (Version 15.1). Mean separation was done where appropriate at a $5 \%$ probability level using Fischer's protected Least Significance Difference test.

\section{Results}

\subsection{Grain Protein Content}

The protein content of finger millet was significantly $(p \leq 0.05)$ influenced by both variety and phosphorus level (Table 2). At Kiboko, the highest protein content $(11.0 \%)$ was observed at the $25 \mathrm{~kg} \mathrm{ha}^{-1} \mathrm{P}_{2} \mathrm{O}_{5}$ rate on variety U-15 while the lowest was at zero P (control) with variety P-224 $(4.4 \%)$. At Kakamega, the highest protein content was observed with the $25 \mathrm{~kg} \mathrm{ha}^{-1} \mathrm{P}_{2} \mathrm{O}_{5}$ treatment $(11.8 \%$ and $15.3 \%$ for the short and long rain seasons, respectively) while, variety P-224 at zero $\mathrm{P}$ had the lowest protein content. At Alupe, a different trend than that of Kiboko and Kakamega was observed in grain protein content. During the long rain season, the highest amount $(15.0 \%)$ was observed at $12.5 \mathrm{~kg} \mathrm{ha}^{-1} \mathrm{P}_{2} \mathrm{O}_{5}$ rate with variety $\mathrm{U}-15$ while during the short rains the local variety, Ikhulule had the highest protein content $(10.9 \%)$ at $12.5 \mathrm{~kg} \mathrm{ha}^{-1} \mathrm{P}_{2} \mathrm{O}_{5}$ rate.

Table 2. Effect of P levels on finger millet varieties grain protein (g/100 g) at Kiboko, Kakamega, and Alupe during the short (SR) and long (LR) growing seasons of 2015.

\begin{tabular}{cccccccc}
\hline & \multicolumn{2}{c}{ Kiboko } & \multicolumn{2}{c}{ Kakamega } & \multicolumn{2}{c}{ Alupe } \\
\hline Variety & $\mathbf{K g ~ h a}^{\mathbf{- 1}} \mathbf{P}_{\mathbf{2}} \mathbf{O}_{\mathbf{5}}$ & $\mathbf{2 0 1 5} \mathbf{~ S R}$ & $\mathbf{2 0 1 5} \mathbf{~ L R}$ & $\mathbf{2 0 1 5} \mathbf{~ S R}$ & $\mathbf{2 0 1 5} \mathbf{~ L R}$ & $\mathbf{2 0 1 5} \mathbf{S R}$ & $\mathbf{2 0 1 5} \mathbf{~ L R}$ \\
\hline $\mathrm{U}-15$ & 0 & $8.79^{\mathrm{b}}$ & $6.56^{\mathrm{c}}$ & $8.92^{\mathrm{c}}$ & $10.94^{\mathrm{c}}$ & $8.75^{\mathrm{b}}$ & $10.94^{\mathrm{c}}$ \\
& 12.5 & $8.83^{\mathrm{b}}$ & $8.75^{\mathrm{b}}$ & $9.75^{\mathrm{b}}$ & $13.13^{\mathrm{b}}$ & $10.70^{\mathrm{a}}$ & $15.01^{\mathrm{a}}$ \\
& 25.0 & $11.00^{\mathrm{a}}$ & $8.75^{\mathrm{b}}$ & $11.8^{\mathrm{a}}$ & $15.31^{\mathrm{a}}$ & $10.93^{\mathrm{a}}$ & $13.12^{\mathrm{b}}$ \\
& 37.5 & $8.854^{\mathrm{b}}$ & $8.75^{\mathrm{c}}$ & $10.95^{\mathrm{a}}$ & $10.94^{\mathrm{c}}$ & $8.75^{\mathrm{b}}$ & $10.94^{\mathrm{c}}$ \\
\hline
\end{tabular}


Table 2. Cont.

\begin{tabular}{cccccccc}
\hline & & \multicolumn{2}{c}{ Kiboko } & \multicolumn{2}{c}{ Kakamega } & \multicolumn{2}{c}{ Alupe } \\
\hline Variety & Kg ha $^{-1} \mathbf{P}_{\mathbf{2}} \mathbf{O}_{\mathbf{5}}$ & $\mathbf{2 0 1 5} \mathbf{~ S R}$ & $\mathbf{2 0 1 5} \mathbf{~ L R}$ & $\mathbf{2 0 1 5} \mathbf{S R}$ & $\mathbf{2 0 1 5} \mathbf{~ L R}$ & $\mathbf{2 0 1 5} \mathbf{S R}$ & $\mathbf{2 0 1 5} \mathbf{~ L R}$ \\
\hline P-224 & 0 & $6.60^{\mathrm{c}}$ & $4.38^{\mathrm{d}}$ & $8.46^{\mathrm{c}}$ & $8.88^{\mathrm{d}}$ & $4.36^{\mathrm{c}}$ & $8.75^{\mathrm{d}}$ \\
& 12.5 & $6.62^{\mathrm{c}}$ & $8.75^{\mathrm{b}}$ & $9.16^{\mathrm{b}}$ & $13.13^{\mathrm{b}}$ & $10.93^{\mathrm{a}}$ & $10.94^{\mathrm{c}}$ \\
& 25.0 & $10.96^{\mathrm{a}}$ & $8.75^{\mathrm{b}}$ & $9.78^{\mathrm{b}}$ & $15.31^{\mathrm{a}}$ & $8.73^{\mathrm{b}}$ & $15.00^{\mathrm{a}}$ \\
& 37.5 & $8.81^{\mathrm{b}}$ & $8.75^{\mathrm{b}}$ & $9.51^{\mathrm{b}}$ & $13.13^{\mathrm{b}}$ & $8.72^{\mathrm{b}}$ & $13.12^{\mathrm{b}}$ \\
\hline Local variety & 0 & $8.81^{\mathrm{b}}$ & $6.56^{\mathrm{b}}$ & $9.12^{\mathrm{b}}$ & $10.80^{\mathrm{c}}$ & $8.75^{\mathrm{b}}$ & $10.94^{\mathrm{c}}$ \\
& 12.5 & $8.79^{\mathrm{b}}$ & $8.75^{\mathrm{b}}$ & $9.49^{\mathrm{b}}$ & $10.94^{\mathrm{c}}$ & $10.94^{\mathrm{a}}$ & $10.94^{\mathrm{c}}$ \\
& 25.0 & $10.98^{\mathrm{a}}$ & $10.94^{\mathrm{a}}$ & $11.48^{\mathrm{a}}$ & $13.13^{\mathrm{b}}$ & $10.93^{\mathrm{a}}$ & $13.12^{\mathrm{b}}$ \\
& 37.5 & $10.96^{\mathrm{a}}$ & $10.94^{\mathrm{a}}$ & $10.67^{\mathrm{a}}$ & $13.13^{\mathrm{b}}$ & $10.91^{\mathrm{a}}$ & $10.94^{\mathrm{c}}$ \\
\hline
\end{tabular}

Values with different letters within each column are significantly different at $5 \%$ probability level, LR: Long rains season, SR: Short rains season, LSD-Least Significance Difference

\subsection{Grain Calcium Content}

Phosphorus application significantly $(p \leq 0.05)$ influenced the calcium content of finger millet grains in all the three sites as shown in Table 3. There was an observable increase in calcium contents with increase in phosphate rates, reaching peak value at $25 \mathrm{~kg} \mathrm{ha}^{-1} \mathrm{P}_{2} \mathrm{O}_{5}$ followed by an observed drastic drop thereafter. At Kakamega, the calcium content peaked at $25 \mathrm{~kg} \mathrm{ha}^{-1} \mathrm{P}_{2} \mathrm{O}_{5}$ with a non-significant increase observed afterwards. At Alupe, an increase in calcium contents led to a concomitant increase in phosphorus application rates in both seasons. The control had the lowest calcium content in all the sites with the short rains season at Kakamega showing only $330 \mathrm{mg} / 100 \mathrm{~g}$ while the control at Kiboko showed $390 \mathrm{mg} / 100 \mathrm{~g}$ during the short rains season. The highest calcium grain content $(472.2 \mathrm{mg} / 100 \mathrm{~g})$ was recorded during the same season in the same site.

Significant varietal differences $(p \leq 0.05)$ were observed in all the sites where variety P-224 showed the highest grain calcium content across the sites (Figure 1). The local variety at Kiboko, Ekalakala, was marginally but not significantly higher than variety U-15 while at Kakamega and Alupe the local variety, Ikhulule had higher calcium content compared to variety U-15. The highest calcium content $(464.4 \mathrm{mg} / 100 \mathrm{~g})$ was recorded in variety P-224 grains harvested at Kiboko during the short rains season.

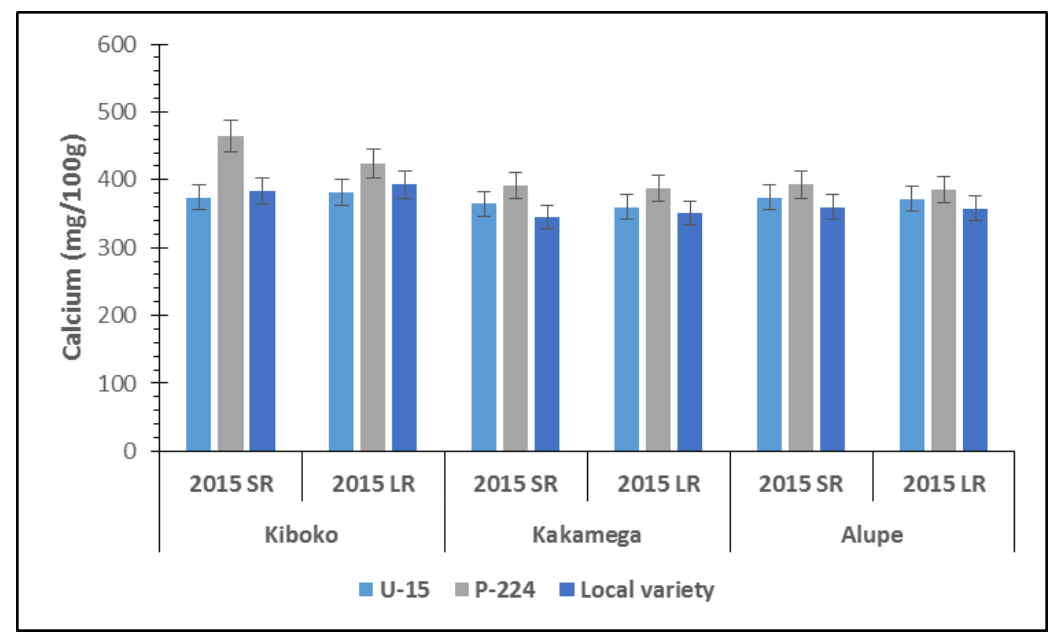

Figure 1. Varietal differences on the grain calcium content of finger millet at Kakamega, Alupe, and Kiboko during the short (SR) and long (LR) rains seasons of 2015. 
Table 3. Effect of phosphorus application rates on the grain calcium content (mg/100 g) of finger millet at the three study sites during the short (SR) and long (LR) rains seasons of 2015.

\begin{tabular}{ccccccc}
\hline & \multicolumn{2}{c}{ Kiboko } & \multicolumn{2}{c}{ Kakamega } & \multicolumn{2}{c}{ Alupe } \\
\hline Kg ha $^{-\mathbf{1}} \mathbf{P}_{\mathbf{2}} \mathbf{O}_{\mathbf{5}}$ & $\mathbf{2 0 1 5} \mathbf{~ S R}$ & $\mathbf{2 0 1 5} \mathbf{~ L R}$ & $\mathbf{2 0 1 5} \mathbf{~ S R}$ & $\mathbf{2 0 1 5} \mathbf{~ L R}$ & $\mathbf{2 0 1 5} \mathbf{~ S R}$ & $\mathbf{2 0 1 5} \mathbf{~ L R}$ \\
\hline 0 & $390^{\mathrm{b}}$ & $382^{\mathrm{b}}$ & $330^{\mathrm{b}}$ & $334^{\mathrm{c}}$ & $334^{\mathrm{c}}$ & $340^{\mathrm{c}}$ \\
12.5 & $424^{\mathrm{ab}}$ & $411^{\mathrm{a}}$ & $349^{\mathrm{b}}$ & $351^{\mathrm{b}}$ & $350^{\mathrm{b}}$ & $350^{\mathrm{b}}$ \\
25 & $472^{\mathrm{a}}$ & $445^{\mathrm{a}}$ & $388^{\mathrm{a}}$ & $394^{\mathrm{a}}$ & $362^{\mathrm{b}}$ & $365^{\mathrm{b}}$ \\
37.5 & $343.3^{\mathrm{c}}$ & $368^{\mathrm{b}}$ & $389^{\mathrm{a}}$ & $399^{\mathrm{a}}$ & $390^{\mathrm{a}}$ & $380^{\mathrm{a}}$ \\
\hline SED & $\mathbf{1 2 . 3}$ & $\mathbf{1 6 . 8}$ & $\mathbf{1 1 . 9}$ & $\mathbf{1 8 . 6}$ & $\mathbf{1 7 . 7}^{\mathbf{3}}$ & $\mathbf{1 4 . 4}$ \\
\hline
\end{tabular}

Values with different letters within each column are significantly different at $5 \%$ probability level, LR: Long rains season, SR: Short rains season, SED-Standard Errors of Differences of Means

\subsection{Grain Iron Content}

Significant differences $(p \leq 0.05)$ between phosphorus treatments were observed in all the sites for both seasons on the grain iron content of finger millet (Figure 2). The control had lowest iron content in all sites with the phosphorus-treated plots showing different trends across sites. At Kiboko, $\mathrm{P}$ treatments did not show significant differences during the short rains where $12.5 \mathrm{~kg} \mathrm{ha}^{-1} \mathrm{P}_{2} \mathrm{O}_{5}$ rate elicited highest iron content $(4.3 \mathrm{mg} / 100 \mathrm{~g})$. In the long rains season, highest rate $\left(37.5 \mathrm{~kg} \mathrm{ha}^{-1}\right.$ $\mathrm{P}_{2} \mathrm{O}_{5}$ ) exhibited a significant decrease in iron content after $25 \mathrm{~kg} \mathrm{ha}^{-1} \mathrm{P}_{2} \mathrm{O}_{5}$ level where the highest iron content was observed. At Kakamega, there was a linear increase on the iron content with increasing phosphorus level for both seasons, however, there were no significant differences between the phosphorus treatments.

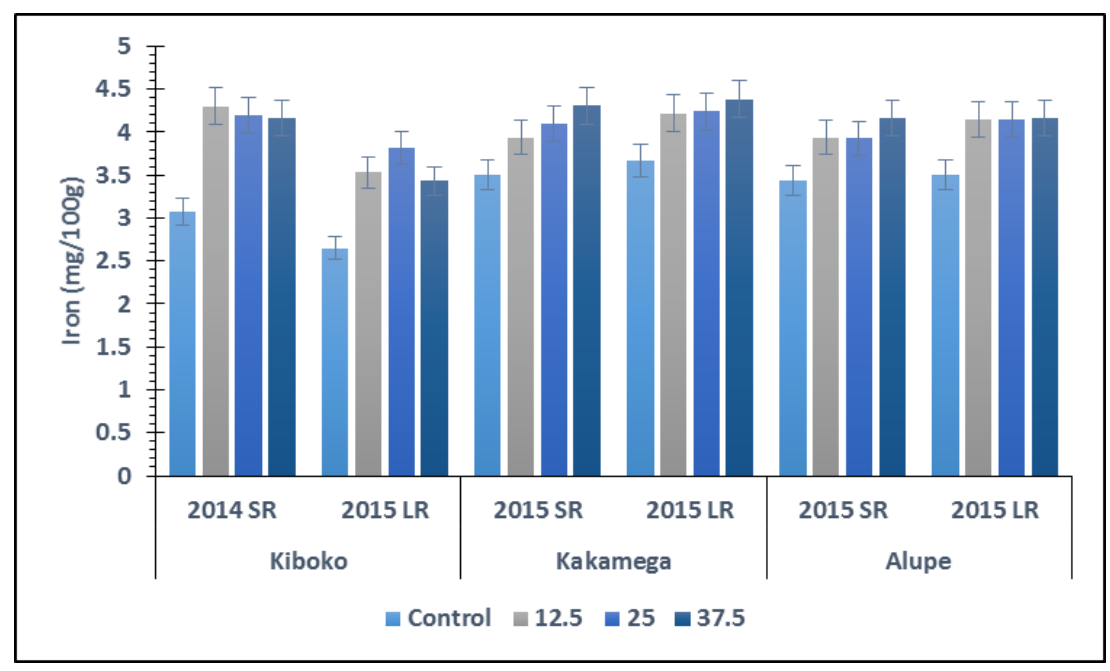

Figure 2. Influence of phosphorus application rates on the finger millet grain iron content at Alupe, Kiboko, and Kakamega during the short (SR) and long (LR) rains seasons of 2015.

The varieties differed significantly on the iron content in all the sites with differing trends (Figure 3). At Kiboko, the local variety, Ekalakala had the highest iron content (4.6 mg/100 g) while the other varieties did not differ significantly. Variety P-224 had the highest iron content at Kakamega for both seasons with $4.7 \%$ and $4.1 \%$ for the long and short rainy seasons respectively. At Alupe, Ikhulule, the local variety exhibited the highest iron content for both seasons while variety U-15 had the lowest. 


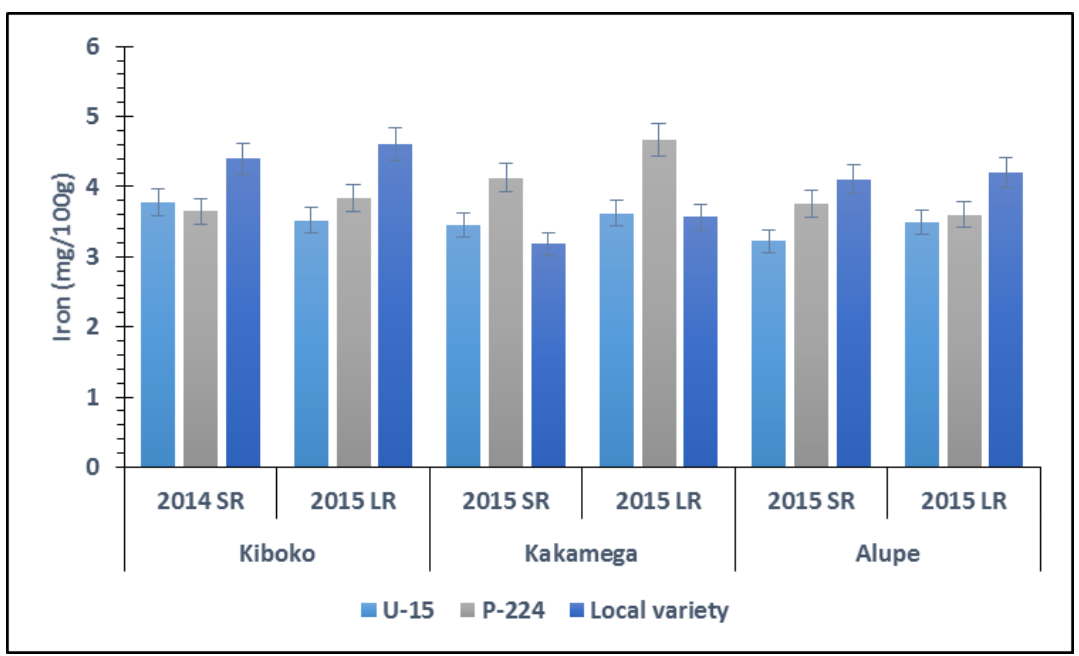

Figure 3. The influence of variety on the grain iron content of finger millet at Kiboko, Kakamega, and Alupe during the short (SR) and long (LR) rain seasons of 2015.

\subsection{Grain Zinc Content}

The grain zinc content was significantly influenced at $p \leq 0.05$ by $P$ rates at all study sites (Table 4). The $12.5 \mathrm{~kg} \mathrm{ha}^{-1} \mathrm{P}_{2} \mathrm{O}_{5}$ rate had the highest zinc content for both seasons at Kiboko with a maximum of $3.53 \mathrm{mg} / 100 \mathrm{~g}$ observed during the long rains season.

Table 4. Effect of phosphorus levels and varieties on zinc content $(\mathrm{mg} / 100 \mathrm{~g})$ in finger millet grain at Kiboko, Kakamega, and Alupe during two seasons in 2015.

\begin{tabular}{ccccccc}
\hline \multirow{2}{*}{ Kg ha $^{-1} \mathbf{P}_{\mathbf{2}} \mathrm{O}_{\mathbf{5}}$} & \multicolumn{2}{c}{ Kiboko } & \multicolumn{2}{c}{ Kakamega } & \multicolumn{2}{c}{ Alupe } \\
\cline { 2 - 7 } & $\mathbf{2 0 1 5} \mathrm{SR}$ & $\mathbf{2 0 1 5} \mathbf{~ L R}$ & $\mathbf{2 0 1 5} \mathrm{SR}$ & $\mathbf{2 0 1 5} \mathbf{~ L R}$ & $\mathbf{2 0 1 5} \mathbf{S R}$ & $\mathbf{2 0 1 5} \mathbf{~ L R}$ \\
\hline 0 & $1.44^{\mathrm{b}}$ & $2.83^{\mathrm{b}}$ & $3.14^{\mathrm{d}}$ & $3.00^{\mathrm{c}}$ & $2.94^{\mathrm{c}}$ & $1.60^{\mathrm{c}}$ \\
12.5 & $1.93^{\mathrm{a}}$ & $3.53^{\mathrm{a}}$ & $3.35^{\mathrm{c}}$ & $3.22^{\mathrm{b}}$ & $3.01^{\mathrm{c}}$ & $1.87^{\mathrm{bc}}$ \\
25 & $1.63^{\mathrm{ab}}$ & $3.43^{\mathrm{a}}$ & $3.65^{\mathrm{b}}$ & $3.06^{\mathrm{c}}$ & $3.11^{\mathrm{b}}$ & $2.10^{\mathrm{b}}$ \\
37.5 & $1.56^{\mathrm{b}}$ & $3.17^{\mathrm{a}}$ & $3.87^{\mathrm{a}}$ & $3.28^{\mathrm{a}}$ & $3.73^{\mathrm{a}}$ & $2.50^{\mathrm{a}}$ \\
\hline Variety & & & & & & \\
\hline U-15 & $1.25^{\mathrm{c}}$ & $2.98^{\mathrm{a}}$ & $2.95^{\mathrm{c}}$ & $3.09^{\mathrm{b}}$ & $3.34^{\mathrm{b}}$ & $1.11^{\mathrm{c}}$ \\
P-224 & $1.29^{\mathrm{b}}$ & $2.29^{\mathrm{b}}$ & $3.21^{\mathrm{b}}$ & $2.83^{\mathrm{c}}$ & $2.80^{\mathrm{c}}$ & $1.70^{\mathrm{b}}$ \\
Local Variety & $1.54^{\mathrm{a}}$ & $3.05^{\mathrm{a}}$ & $3.54^{\mathrm{a}}$ & $3.50^{\mathrm{a}}$ & $3.45^{\mathrm{a}}$ & $3.25^{\mathrm{a}}$ \\
\hline Interaction & $\mathrm{NS}$ & $\mathrm{NS}$ & $\mathrm{NS}$ & $\mathrm{NS}$ & $\mathrm{NS}$ & $\mathrm{NS}$
\end{tabular}

Values with the same letters within each columns for P treatments and variety are not significantly different at $5 \%$ probability level, LR: Long rains season, SR: Short rains season, NS: Not significant.

At Kakamega and Alupe, the highest phosphorus rate led to the highest grain zinc content with the short rains at Kakamega eliciting the maximum amount $(3.87 \mathrm{mg} / 100 \mathrm{~g})$. The control (zero P) exhibited the lowest zinc grain content in all the sites for both seasons. The varieties differed significantly in all the sites on the zinc content where the local varieties exhibited the highest. Varieties U-15 and P-224 had significantly lower levels of zinc content but there could be no conclusion as to which between them was superior as the pattern interchanged seasonally in all the sites.

\section{Discussion}

The grain protein increase with increasing phosphorus application rates is probably due to the significance of $\mathrm{P}$ in the synthesis of protein where it acts as an important building part in the amino acids and provision of energy needed for the uptake and transfer of $\mathrm{N}$ in the grains of finger millet [15]. 
The grain endosperms are also the primary sinks for carbon and $N$ compounds [16] and this enhanced the protein content. Several other authors have also reported similar observations. For example, an $8 \%$ increase in crude protein of cowpea was recorded with $37.5 \mathrm{~kg} \mathrm{P} \mathrm{ha}^{-1}$ compared to zero P application in Northern Guinea Savanna of Nigeria [17]. Ali and Mohamad [18] also reported that higher P application led to higher protein content $(10.8 \%)$ with minimum protein content $(9.5 \%)$ recorded in control plots of maize. Other studies showed that percentage of lentil seed protein content was increased by applying $40-60 \mathrm{~kg} \mathrm{P} /$ ha by $8 \%$ over the control $[19,20]$. Finger millet has high genetic diversity [21] and therefore response to nutrients can vary as shown in the current study. Genotypic variability between the different finger millet varieties on grain quality observed in the study has also been described by Bhoite and Nimbalkar [22] as an effect of responsiveness to nitrogen and phosphorus by cultivars.

The differential calcium content between the sites might be due to the amount of calcium content in the soil where Kiboko had higher amounts than Kakamega and Alupe. Application of phosphorus probably enhanced exchange reactions in the soil by releasing hydrogen ions in the microbial biomass that probably resulted in more availability of $\mathrm{Ca}$. Hence, the concentration of this nutrient in the soil solution increased, improving root architecture and energy provision through ATP leading to uptake of more quantities of calcium which were partitioned to the grains $[23,24]$.

Phosphorus is vital in activating various metabolic processes and building plant tissues, therefore its application enhanced the uptake of iron. The increase in iron content in grain could also be due to the P impact on root development that resulted in higher uptake of iron. Increasing grain iron content has a great potential in combating iron deficiency in diets and should have a significant impact on human health [25]. The findings showed higher amounts of iron in the P-224 variety grains compared to those reported by Rao et al. [26] than in selected varieties of finger millet for malting the iron content was around $8.4 \mathrm{mg} / 100 \mathrm{~g}$, while the local variety at Kiboko and P-224 at Kakamega elicited higher iron contents than that reported to be the average for finger millet grains ( $3.9 \mathrm{mg} / 100 \mathrm{~g}$ ) by Dayakar et al. [12]. The genetic variability in nutrient accumulation has also been reported in a study by Jahan et al. [27] who screened 52 rice genotypes for iron concentration and found that there was an extensive range of variation from $1.32 \mathrm{mg} / \mathrm{kg}$ to $100.45 \mathrm{mg} / \mathrm{kg}$. Among 126 accessions of brown rice genotypes, Anuradha et al. [28] also reported that iron concentration ranged from $6.2 \mathrm{mg} / \mathrm{kg}$ to $71.6 \mathrm{mg} / \mathrm{kg}$ where the local accessions had the highest concentration of iron.

Depending on the soil type, application of $\mathrm{P}$ beyond optimum levels can lead to negative interactions with micronutrients such as $\mathrm{Zn}$ and that is why at Kiboko it peaked at the $12.5 \mathrm{~kg} \mathrm{ha}^{-1}$ $\mathrm{P}_{2} \mathrm{O}_{5}$ and a decrease followed thereafter. This agreed with previous work [29] which found that beyond $40 \mathrm{~kg} \mathrm{ha}^{-1} \mathrm{P}_{2} \mathrm{O}_{5}$, the tissue mineral content of two amaranth varieties started to decrease. This finding on the increase of grain zinc content with increasing phosphorus are in tandem with those of Loneragan et al. [30] that $\mathrm{P}$ application increased the total zinc content accumulation in millet grain of up to $28 \%$ due to growth promotion by supplementing P. Therefore, the understanding of optimal plant nutrient requirements is imperative in sustaining the soil environment for cases where higher than optimal P fertilizers lead to increased production costs and negative interaction in uptake of micronutrients such as zinc $[15,31]$.

\section{Conclusions}

The study demonstrated that application of phosphorus is important in enhancing the protein, calcium, iron, and zinc contents of finger millet and has potential in addressing nutritional and food security challenges, particularly among the vulnerable farmers in Sub-Saharan Africa. Therefore, based on the results, the application of $25 \mathrm{~kg} \mathrm{ha}^{-1} \mathrm{P}_{2} \mathrm{O}_{5}$ rate is strongly recommended for Kiboko and Kakamega while $12.5 \mathrm{~kg} \mathrm{ha}^{-1} \mathrm{P}_{2} \mathrm{O}_{5}$ rate is recommended for Alupe. The local varieties should not be ignored because, as observed in all the sites, they contained the highest grain zinc content and highest iron content at Kiboko, breeders can consider this trait during selection to improve other cultivars. 
Acknowledgments: The authors wish to appreciate the financial support from the International Crops Research Institute for the Semi-Arid Tropics (ICRISAT)-Nairobi and all the staff of the organization as well as all those who contributed to the success of this project.

Author Contributions: Moses Siambi conceived the experiment; Wekha N. Wafula and Henry F. Ojulong conducted the experiment; Nicholas K. Korir analyzed and interpreted the data; Wekha N. Wafula and Joseph P. Gweyi-Onyango wrote the manuscript with significant contributions from Henry F. Ojulong.

Conflicts of Interest: All authors have declared no conflict of interest. The funding agencies did not have any direct influence in setting the experiment through to the decision of publishing the findings which was solely attributed to the authors.

\section{References}

1. Quattrocchi, U. CRC, World Dictionary of Grasses: Common Names, Scientific Names, Eponyms, Synonyms, and Etymology; CRC Press: Boca Raton, FL, USA, 2006.

2. De Wet, J.M.J. Eleusine Coracana (L.) Gaertn. Record from Protabase; Brink, M., Belay, G., Eds.; PROTA (Plant Resources of Tropical Africa/Ressources végétales de l'Afriquetropicale): Wageningen, The Netherlands, 2006.

3. Food and Agriculture Organization (FAO). Grassland Index. A Searchable Catalogue of Grass and Forage Legumes; FAO: Rome, Italy, 2012.

4. Dida, M.M.; Devos, K.M. Finger millet. In Genome Mapping and Molecular Breeding in Plants; Chittarajan, K., Ed.; Springer: New York, NY, USA, 2006; Volume 1, pp. 333-344.

5. Saleh, A.S.M.; Zhang, Q.; Chen, J.; Shen, Q. Millet grains: Nutritional Quality, Processing, and Potential Health Benefits. Compr. Rev. Food Sci. Food Saf. 2013, 12, 281-295. [CrossRef]

6. Amadou, I.; Gbadamosi, O.S.; Guo-Wei, L. Millet-based traditional processed foods and beverages-A review. Cereal Food World 2011, 56, 115-121. [CrossRef]

7. Izadi, Z.; Nasirpour, A.; Izadi, M.; Izadi, T. Reducing blood cholesterol by a healthy diet. Int. Food Res. J. 2012, 19, 29-37.

8. Mbithi, M.S.; Ooghe, W.; Van Camp, J.; Nagundi, D.; Huyghebaert, A. Amino acid profile after sprouting, autoclaving and lactic acid fermentation of finger millet (Elusine coracana) and kidney beans (Phaseolus vulgaris L.). J. Agric. Food Chem. 2000, 48, 3081-3085. [CrossRef]

9. Food and Agriculture Organization (FAO). Amino Acid Scoring Pattern. In Protein Quality Evaluation; FAO/WHO Food and Nutrition Paper: Rome, Italy, 1991; pp. 12-24.

10. Obilana, A.B.; Manyasa, E. Millets. In Pseudocereals and Less Common Cereals: Grain Properties and Utilization Potential; Belton, P.S., Taylor, J.R.N., Eds.; Springer: New York, NY, USA, 2002; pp. 177-217.

11. Dayakar, R.B.; Bhaskarachary, K.; Rajendra, P.M.P.; Bala, K.D.; Dhanasri, K.; Nageswara, R.T.G. Nutritional and Health Benefits of Millets; ICAR—Indian Institute of Millets Research: Rajendranagar, Hyderabad, India, 2016.

12. Fairhurst, T.; Lefroy, R.; Mutert, E.; Batjes, N. The importance, distribution and causes of phosphorus deficiency as a constraint to crop production in the tropics. Agrofor. Forum 1999, 9, $2-7$.

13. Jama, B.; van Straaten, P. Potential of East African phosphate rock deposits in integrated nutrient management strategies. Ann. Brazil. Acad. Sci. 2006, 78, 781-790. [CrossRef]

14. Association of Official Analytical Chemists (AOAC). Officials Methods of Analysis, 17th ed.; Revision 2; AOAC International: Gaithersburg, MD, USA, 2007.

15. Wekha, N.W.; Nicholas, K.K.; Henry, F.O.; Moses, S.; Joseph, P.G.O. Phosphorus Influence on Plant Tissue Nitrogen Contents and Yield Attributes of Finger Millet Varieties in Semi-arid Region of Kenya. Int. J. Plant Soil Sci. 2016, 13, 1-9.

16. Balconi, C.; Bosio, D.; Rizzi, E.; Nembrini, L.; Motto, M. Effects of organic and inorganic N supplies on protein and carbohydrates accumulation in high and low protein maize endosperms grown in vitro. Maydica 1997, 42, 257-264.

17. Magani, I.E.; Kuchinda, C. Effects of phosphorus fertilizer on growth, yield and crude protein content of cowpea (Vigna unguculata [L.] Walp) in Nigeria. J. Appl. Biosci. 2009, 23, 1387-1393.

18. Ali, S.; Mohamad, H.S. The effects of nitrogen fertilizer on ash, nitrate, organic carbon, protein and total yield of forage maize in semi-arid region of Iran. Tech. J. Eng. Appl. Sci. 2013, 3, 1680-1684.

19. Togay, Y. The Effect of Different Zinc and Phosphorus Levels on the Yield and Yield Components in Lentil (Lens culinaris Medic). Ph.D. Thesis, Yuzuncu Yil University, Van, Turkey, 2002. 
20. Togay, Y.; Togay, N.; Dogan, Y. Research on the effect of phosphorus and molybdenum applications on the yield and yield parameters in Lentil (Lens culinaris Medic). Afr. J. Biotechnol. 2008, 7, 1256-1260.

21. Goron, T.L.; Raizada, M.N. Genetic diversity and genomic resources available for the small millet crops to accelerate a new green revolution. Front. Plant Sci. 2015, 6, 157. [CrossRef] [PubMed]

22. Bhoite, S.V.; Nimbalkar, V.S. Response of finger millet cultivars to nitrogen and phosphorus under rain-fed condition. J. Maharashtra Agric. Univ. 1996, 20, 189-190.

23. Sarwar, G.; Hussain, N.; Schmeisky, H.; Muhammad, S.; Ibrahim, M.; Safdar, E. Use of compost an environment friendly technology for enhancing rice-wheat production in Pakistan. Pak. J. Bot. 2008, 40, 1553-1558.

24. Brady, N.C.; Weil, R.R. The Nature and Properties of Soil, 13th ed.; Macmillan Publishing Co.: New York, NY, USA, 2005.

25. Clemens, S.; Palmgren, M.G.; Krämer, U. A long way ahead: Understanding and engineering plant metal accumulation. Trends Plant Sci. 2002, 7, 309-315. [CrossRef]

26. Rao, B.K.R.; Krishnappa, K.; Srinivasarao, C.; Wani, S.P.; Sahrawat, K.L.; Pardhasaradhi, G. Alleviation of multi-nutrient deficiency for productivity enhancement of rain-fed soybean and finger millet in the semi-arid region of India. Soil Sci. Plant Anal. 2012, 43, 1427-1435.

27. Jahan, G.; Hassan, S.L.; Begum, S.N.; Islam, S.N. Identification of iron rich rice genotypes in Bangladesh using chemical analysis. J. Bangladesh Agric. Univ. 2013, 11, 73-78. [CrossRef]

28. Anuradha, K.S.; Agarwal, Y.V.; Rao, K.V.; Rao, B.C.; Viraktamath, C.; Sarla, N. Mapping QTLs and candidate genes for iron and zinc concentrations in unpolished rice of Madhukar $\times$ Swarna RILs. Gene 2012, 508, 233-240. [CrossRef] [PubMed]

29. Ogembo, J.O. Effects of Phosphorus Deficiency on Secondary Metabolites and Distribution of African Nightshade in Siaya and Kisii Counties, Kenya. Ph.D. Thesis, Kenyatta University, Nairobi, Kenya, 2015.

30. Loneragan, J.F.; Grove, T.S.; Robson, A.D.; Snowball, K. Phosphorus toxicity as a factor in zinc-phosphorus interaction in plants. Soil Sci. Soc. Am. J. 1979, 43, 966-972. [CrossRef]

31. International Food Policy Research Institute. Transform Nutrition Kenya Stakeholder Mapping Report. Available online: www.transformingnutrition.org/files/2011/11/kenya_situation_analysis.pdf (accessed on 20 December 2016). 